Yan Brecko, Ing. Mgr., Director MERKUR - Vocational Education Academy Kaluza, Slovak Republic ORCID: 0000-0002-0247-3990

Peter Sklencar, Phd., MBA, Professor MERKUR - Vocational Education Academy Kaluza, Slovak Republic ORCID: 0000-0001-5573-1984

\title{
THE TRANSFORMATION OF ASPIRATIONS AND THE BEHAVIOR OF MODERN TOURISTS
}

Tourists' preferences, aspirations and behaviour change under the influence of dynamic and sweeping social changes. These factors should also be taken into account by all business entities involved in the tourist service process: hotels, restaurants, vehicles, entertainment establishments. The factors of change of behaviour and aspirations of modern tourists are substantiated in this work. The transformation of tourist under the influence of these factors is shown.

Key words: tourism, tourist, tourist aspirations, tourist behaviour, New Age tourism.

\section{Relevance of research topic}

The dynamic development of the modern world is impressive. The tourism sector is transforming under the influence of global trends predetermined by innovative technologies, political, socio-economic and cultural changes. The changes in tourists' aspirations and behaviour are particularly evident. These aspects are relevant and problematic for tourism.

\section{Formulation of the problem.}

Changes in tourists' aspirations and behaviour are latent and often implicit, however, they should be identified and taken into account in the business practices of all business entities involved in the tourist service process. It is important to build own business models based not on catching behaviour, but on the contrary, offer tourists the innovations that they subconsciously need. Therefore, the diagnosis of modern tourists, their differences from the tourists of previous generations is an important scientific and practical problem that should be addressed. 


\section{Analysis of recent researches and publications.}

P. Sutton and J. House (2007) explore tourism in the postmodern era and they conclude that «on the horizon of the postmodern landscape, a New Age of tourism is dawning: New Age tourism for New Age people». In general, the New Age movement is a Western spiritual and metaphysical movement that is a holistic worldview with a focus on the interconnection and unification of mind, body and spirit; purposeful focus on real self; movement of human potential (Gisolf, 2013). When this self-development and realization is manifested in leisure, it can be accordingly considered a «new time of tourism», and its essence is to study alternative culture as leisure; it is a manifestation of identity as well as sustainable tourism (P. Sutton, J. House, 2007).

P. Sutton, J. House (2007) explore the modern period of tourism development and draw attention to the fact that «we will now apply the idea of the postmodern to New Age tourism through an analysis of four regions of the postmodern landscape: hyperreality, egocentricity, ephemerality and incredulity».

The opinions of the main groups of components of the tourist systems that have undergone the most significant changes, such as 1) new consumers; 2) new technologies; 3) new forms of production; 4) new management styles; 5) new prevailing circumstances (Poon, 1993, p. 123) are still relevant today.

Thus, unlike the «old» tourists (their features are justified in the works of D. MacCannell (1973); E. Cohen (1979) «new tourists» are forming now, travel is a common, self-evident thing for them in search of self-expression; they widely use digital technology and strive for sometimes quite polar goals such as 1) convenience and comfort/primitive and archaic conditions; 2) focus on a particular aspect/need for diversity; 3) the combination of the incompatible and so on. M. Gisolf (2013) notes that «the sheer observation of individualist tourism increasing at both sides of the tourism life style scale at the same time shows us first of all that tourists are increasingly looking for their own way to go and under the influence of postmodern tendencies they seek a more independent role in tourism».

$\mathrm{R}$. Thaler argues that people are tempted and often act irrationally, according to the theory of rational choice at the present stage, and their actions will not be always justified (Thaler 2015). The need for a study of consumer behaviour, in this case tourists, is confirmed by R. Thaler's research on behavioural economics and the award Nobel Prize in Economics for him in 2017.

A. Raj (2007) in his study describes a new tourist with the abbreviation «REAL», formed from the first letters of the words that are his characteristic features Rewarding, Enriching, Adventuresome, Learning Experience, («reward (benefit)», «enrichment», «adventures», «learning experiences»).

Generalizations of tourist transformations are also reflected in A. Okhrimenko's (2019) monograph, however, the need to address these issues and evaluate them from new perspectives requires research. 


\section{Presenting main material}

Due to the dynamic changes in society, tourists are changing as well. R. Sutton, J. House (2007) consider that «the new tourist is characterized by the desire for ecology, social responsibility, constructive and mutually beneficial interaction between the guest and the host, and this «New Age of tourism» can be considered as a mixture of identity tourism (identity tourism) and sustainable tourism, which is definitely a rejection of existing mass tourism». T. Pernecky (2006, p. 127) has the same opinion: «New Age tourists are highly individual persons who are characterized by their interest in a unique life experience, are notable for the search of extraordinary and awareness that goes beyond (transcendental) boundaries, and their goals include personal, spiritual and emotional growth». Summarizing the research of scientists, we can reflect the transformation of views on the vision of the tourist (Table 1).

Table 1

\section{Transformation of views on the vision of the tourist}

\begin{tabular}{|c|c|c|}
\hline Old tourist & Need for «the sun» & New tourist \\
\hline $\begin{array}{c}\text { Nnheritance of the masses (majority) } \\
\text { future is far away» }\end{array}$ & $=>$ & $\begin{array}{c}\text { Need for experience and other } \\
\text { competencies }\end{array}$ \\
\hline $\begin{array}{c}\text { A simple statement that a person has } \\
\text { been in a certain place }\end{array}$ & $=>$ & $\begin{array}{c}\text { Desire for review, enjoyment, but not } \\
\text { destruction }\end{array}$ \\
\hline Availability & $=>$ & Enjoyment \\
\hline Advantage & $=>$ & Being \\
\hline Activity is similar to sightseeing & $=>$ & $\begin{array}{c}\text { Activity is similar to sports, movement, } \\
\text { mobility }\end{array}$ \\
\hline Need for security measures & $\Rightarrow>$ & Need for adventures \\
\hline Preference of food at the hotel & $\Rightarrow>$ & $\begin{array}{c}\text { Desire to get an impression of local } \\
\text { cuisine }\end{array}$ \\
\hline Ecology is not important & $\Rightarrow>$ & Emphasis on environmental friendliness \\
\hline Absence of sweeping aspirations & $\Rightarrow>$ & $\begin{array}{c}\text { Need for creative approaches to the } \\
\text { organization and content of travel }\end{array}$ \\
\hline Homogeneous & $\Rightarrow>$ & Hybrid \\
\hline
\end{tabular}

Source: revised on the base of Poon A., 1993; Pernecky T., 2006; Sutton P., House J., 2007; Raj A., 2007; Okhrimenko, A., 2019

Change of generations is the special factor in the transformation of tourists'behavior, these problems are highlighted in the researches of G. Moscardo, P. Beckendorff (2007), Veiga, C., Santos M.C., Aguas P., Santos J.A. (2017); Starcevic S., Konjikusic S. (2018). For example, «They are not just (millennials) - one 
new generation in tourism, but consumers with completely different behaviour and motivation compared to previous generations, which are particularly caused by their maturation accompanied by digital technologies» (G. Moscardo, P. Beckendorff, 2007). Moreover «Millennials understand that, as citizens, they must help improve the world in which they live, so they highly value volunteer tourism options» (Veiga, C., Santos M.C., Aguas P., Santos J.A. $(2017,612)$ and «At the moment, they (authors': millennials) form almost one third of the world's population» (Hamed, 2017).The changes in the technological advantages and needs of modern tourists are particularly noteworthy, especially for the tourists born at the turn of the millennium - the millennials. So their skills in using digital technologies, creating new content, engaging in social networks, change in general the approaches to the organization, implementation and consumption of the tourism product.

It should also be added that the image of the new tourist is extremely generalized and is determined by the country of origin, habitat, social status, psychological characteristics, but considering such a holistic picture will contribute to a better understanding of the tourist system.

\section{Conclusions.}

Changes in the preferences and behavior of modern tourists are a characteristic feature of the development of tourism systems at different levels. The tourists are also changing under the influence of global and local trends related to digitazation, the formation of the knowledge economy, psychological and mental factors. These phenomena lead to a vision of new tourism - New Age tourism. The modern tourist is characterized by the constant need for trips that become part of his life, as well as the need for individuality, creative approaches, wide spreaduse of innovative technologies. Tourists themselves become the organizers and motivators of their journey, they seek new knowledge and experience.

\section{REFERENCES}

1. CohenE. (1979). A phenomenology of tourist experiences. Sociology. 13(2). P. 179-210.

2. Gisolf M.C. (2013). A New Age in Tourism. A case study of New Age centres in Costa Rica. Routledge, Oxon.

3. Hamed, H.M. (2017). Marketing destinations to millennials: Examining the compatibility between the destination marketing organization website and the millennial tourist prospects. Journal of Tourism and Recreation, Vol. 3, No. 1, 1-20.

4. MacCannell D. (1973). 'Staged authenticity: arrangements of social space in tourist settings'. American Sociological Review. P. 589-603. 
5. Moscardo, G., Beckendorff, P. (2007). Misunderstanding generation Y: risks for tourism managers. Proceedings of the 2007 TTRA Annual Conference, Las Vegas, 203-211.

6. Okhrimenko, A. (2019). Natsional'na turystychna systema [National tourism system], Kyivs'kyj natsional'nyj torhovel'no-ekonomichnyj universytet, Kyiv, Ukraine [inUkrainian].

7. Pernecky, T. (2006). Co-creating with the universe: A phenomenological study of New Age tourists. Tourism - An International Interdisciplinary Journal. Vol. 54 (2). 127-143. Retrieved from http://www.iztzg.hr/en/publications/tourism/ latest_issue/?clanakId $=98 \&$ brojId $=6]$

8. Poon, A. (1993). Tourism, Technology and Competitive Strategies. CABI Publishing.

9. Raj, A. (2007). The New Age of Tourism - And the New Tourist. Institute of Tourism and Hotel Management, Bundelkhand University. Retrievedfromhttp: // www.indianmba.com/Faculty_Column/FC565/fc565. html

10. Starcevic S., Konjikusic S. (2018). Why millennials as digital travelers transformed marketing strategy in tourism industry. /monograph Tourism in funcion of development of the Republic of Serbia - Tourism in Era of digital transformation, Univerzitet u Kragujevcu, Fakultet za hotelijerstvo i menadžment, pp. 221-240.

11. Sutton P., House J. (2007). The New Age of Tourism: Postmodern Tourism for Postmodern People? Retrieved from http://www.arasite.org/pspage2.htm

12. Thaler R. H.(2015). Misbehaving: The Making of Behavioral Economics. New York: W. W. Norton \& Company.

13. Veiga, C., Santos M.C., Aguas P., Santos J.A. (2017). Are millennials transforming global tourism? Challenges for destinations and companies, Worldwide Hospitality and Tourism Themes, Vol. 9, No. 6, 603-616. 